\title{
A REVIEW ON BIOSORPTION OF CHROMIUM IONS BY MICROORGANISMS
}

\author{
Inga Zinicovscaia ${ }^{1,2}$ \\ ${ }^{1}$ Joint Institute for Nuclear Research, Joliot-Curie Str., 6, 1419890 Dubna, Russia \\ ${ }^{2}$ The Institute of Chemistry of the Academy of Sciences of Moldova, 3, Academiei Str., 2028 Chisinau, R. Moldova \\ E-mail: zinikovskaia@mail.ru
}

\begin{abstract}
Due to its widespread industrial use, chromium has become a serious pollutant in diverse environmental settings. The main source of chromium pollution including the Republic o Moldova is industry. It is a great need to develop new eco-friendly methods of chromium removal. Biosorption of heavy metals is a most promising technology involved in the removal of toxic metals from industrial waste streams and natural waters. Metal removal treatment systems using microorganisms are cheap because of the low cost of sorbent materials used and as they do not add other ions or toxic chemicals to the environment. The present review discusses hexavalent chromium biosorption properties of bacteria, microalgae and fungi, as well as adsorption isotherms (Langmiur, Freundlich, Langmiur-Freundlich) used in the evaluation of the adsorptive capacity of the biomaterial.
\end{abstract}

Keywords: chromium, biosorption, bacteria, microalgae, fungi.

\section{Introduction}

Industrial activities have led to large-scale contamination of the environment with toxic heavy metals and radionuclides [1].

Hexavalent chromium $\mathrm{Cr}(\mathrm{VI})$ is one of the most common environmental metal contaminant released primarily from industries such as leather tanning, metal plating and alloying, wood preservation [2, 3], electroplating, paint and pigment manufacturing, textile and fertilizer industries [4].

Chromium exists in 9 valence states ranging from -2 to +6 . Nevertheless, only hexavalent chromium $\mathrm{Cr}$ (VI) and trivalent chromium $\mathrm{Cr}$ (III) are ecologically more important because they are the most stable oxidation forms in the natural environment [4-6].

$\mathrm{Cr}(\mathrm{VI})$ is known to be highly toxic, mutagenic and carcinogenic to living organisms including mammals. Highly water soluble $\mathrm{Cr}(\mathrm{VI})$ compounds move fairly rapidly in the subsurface and can readily enter a cell via surface anion transport systems $\left(\mathrm{SO}_{4}{ }^{2-}\right.$ channels). [2]. $\mathrm{Cr}(\mathrm{VI})$ is usually associated with oxygen as chromate $\left(\mathrm{CrO}_{4}{ }^{2-}\right)$ or dichromate $\left(\mathrm{Cr}_{2} \mathrm{O}_{7}^{2-}\right)$ ions [6]. $\mathrm{Cr}(\mathrm{III})$, on the other hand, is more stable and is approximately 100 times less toxic and 1000 times less mutagenic than $\mathrm{Cr}(\mathrm{VI})[4,6]$.

Therefore there is a great need to remediate harmful $\mathrm{Cr}(\mathrm{VI})$. Though there are various physicochemical methods for the treatment of $\mathrm{Cr}(\mathrm{VI})$ such as: reduction, precipitation, ion- exchange, reverse-osmosis, electrodialysis [7], but it has been observed that these conventional methods have several disadvantages, such as high operating costs, the necessity of preliminary treatment steps, the difficulty of treating the solid waste subsequently generated, and the requirement of large quantities of chemical adsorbents $[4,8,9]$.

In recent years, applying biotechnology in controlling and removing metal pollution has been paid much attention, and gradually becomes hot topic in metal pollution control practices because of its potential application. A practical and dynamic approach is the use of biological agents (microorganisms) which include bacteria, microalga, yeast, and their products [10].

Biosorption is gaining interest among researchers due to several advantages that include possibility of recovery of metal; good performance, low cost of the process [11-15]; high efficiency and selectivity for absorbing heavy metals in low concentrations, energy-saving, broad operational range of $\mathrm{pH}$ and temperature, easy reclamation of heavy metal and easy recycling of the biosorbent [16-19], toxicity of the metals in solution cannot affect the adsorptive function of the biomass [20], waste from the processes is readily treated and can be easily disposed by incineration. Biosorption employs inexhaustible, inexpensive and non hazardous materials [12].

Biosorption is possible with both living and non-living biomass [11]. The metal ion uptake by living and dead cells consists of two modes. The first uptake mode involves the surface binding of metal ions to cell wall and extracellular material. The second mode of metal uptake into the cell across the cell membrane is dependent on the cell metabolism and is referred to as intracellular uptake, active uptake or bioaccumulation. The first mode is common to metal adsorption

\footnotetext{
" This article is an extended abstract of a communication presented at the Conference Ecological Chemistry 2012
} 
by both living and dead cells; the second mode, which is metabolism dependent, occurs in living cells. Bioaccumulation mechanisms include precipitation, intracellular accumulation, and oxidation or reduction [10].

The main aim of this work is to summarize the results of chromium removal by microorganisms and to demonstrate the possibility of their use for solution of industrial tasks of the Republic of Moldova.

\section{Chromium removal by microorganisms}

\section{Chromium removal by bacterial biomass}

Bacteria make excellent biosorbents because of their high surface-to-volume ratios and a high content of potentially active chemosorption sites such as on teichoic acid in their cell walls. Bacteria were used as biosorbents because of their small size, their ubiquity, their ability to grow under controlled conditions, and their resilience to a wide range of environmental situations [11].

Alam et al. [10] conducted an experiment for $\mathrm{Cr}(\mathrm{VI})$ biosorption using Exiguobacterium sp. ZM-2, S. maltophilia ZA-6, Pantoea sp. KS-2 and Aeromonas sp. KS-14 and found a maximum biosorption at pH 2.5 during the first 15 min. Electron micrographs confirmed the bioaccumulation of chromium in the test bacterial isolates. Chromate sensitive isolates Pantoea sp. KS-2 and Aeromonas sp. KS-14 were not efficient chromate reducers. Pseudomonas aeruginosa and Bacillus subtilis adsorb $\mathrm{Cr}(\mathrm{VI})$ at $\mathrm{pH} 2$ and temperature $32^{\circ} \mathrm{C}$ [21].

Non-living biomass of Aeromonas caviae presents sufficient biosorption capacity for $\mathrm{Cr}(\mathrm{VI})$ anions [22]. Chroococcus sp. HH-11 was found to be suitable for the development of an efficient biosorbent for the removal of $\mathrm{Cr}(\mathrm{VI})$ from wastewater [23].

The greatest capacity of biosorption for $\mathrm{Cr}(\mathrm{VI})$ ions by Pantoea sp. TEM18. was obtained at $\mathrm{pH}$ 3.0. The biosorption capacity of the biomass increased first with increasing of the initial concentration of metal ions and reached a saturated value. Chromium (VI) concentration was increased from 28.9 to $245.2 \mathrm{mg} / 1$ approximately, the loading capacity increased from 7.81 to $53.8 \mathrm{mg} / \mathrm{g}$ of Pantoea sp. TEM18 [24]. Micrococcus sp. reported a maximum removal for $\mathrm{Cr}(\mathrm{VI})(90 \%)$ at $\mathrm{pH} 7.0[25]$.

$\mathrm{Cr}(\mathrm{VI})$ can be efficiently removal by Azotobacter chroococcum, Bacillus sp. and Pseudomonas fluorescens [26], S. saprophyticus [27], Bacillus licheniformis [28], E. coli ASU 7[29], Pseudomonas species [30], Acinetobacter haemolyticus [31].

\section{Chromium removal by microalgae}

Chromium biosorption by microlgae Phormedium bohneri, Oscillatoria tenuis, Chlamydomonas angulosa, Ulothrix tenuissima was investigated. The maximum accumulation of $\mathrm{Cr}$ was shown by Phormedium bohneri (8550 $\mu \mathrm{g} / \mathrm{g}$ ) followed by Oscillatoria tenuis $(7354 \mu \mathrm{g} / \mathrm{g})$, Chlamydomonas angulosa $(5325 \mu \mathrm{g} / \mathrm{g})$, Ulothrix tenuissima (4564 $\mu \mathrm{g} / \mathrm{g}$ ), and Oscillatoria nigra (1862 $\mu \mathrm{g} / \mathrm{g})$; all of which demonstrated a transfer factor of $>10 \%$ for $\mathrm{Cr}$ [32].

Adsorption of $\mathrm{Cr}(\mathrm{VI})$ by heat-dried biomass of the cyanobacterium Phormidium laminosum has been reported at $\mathrm{pH} 2.0$ [33].

Biosorption of chromium by residual Nannochloris oculata after lipid extraction was investigated. Increased surface area of $N$. oculata was observed after lipid extraction. $\mathrm{Cr}(\mathrm{VI})$ removal was highest at $\mathrm{pH} 2$ and it decreased with the increase in $\mathrm{pH}[34]$.

Travieso et al. have demonstrated better Cr removal efficiencies by Scenedesmus acutus than Chlorella vulgaris [35] Chlorella pyrenoidosa, Spirulina maxima, Spirulina platennis, Selenastrum capriornutum and Scenedesmus quadricauda [36] can be successfully used for chromium biosorption.

\section{Chromium removal by fungi}

Fungi are the organisms which are used as biosorbents for the removal of heavy metals due to the production of high yields of biomass. They grow easily under wide range of environmental situations and can also be modified genetically to produce enzymes (reductase, DNA polymerase etc.), which are helpful in higher metal removal from the wastewaters. In general, the fungal organisms are resistant to higher metal ion concentrations. A wide range of fungal species under nonliving condition have been studied by different researchers for the removal of $\mathrm{Cr}(\mathrm{VI})$ from the wastewaters [37].

Chen et al. [38] investigated the effects of $\mathrm{pH}$, initial concentration, and sorption time on $\mathrm{Cr}(\mathrm{VI})$ removal by polyethylenimine (PEI)-modified Phanerochaet chrysosporium. The optimum $\mathrm{pH}$ was approximately 3.0. The maximum removal for $\mathrm{Cr}(\mathrm{VI})$ was $344.8 \mathrm{mg} / \mathrm{g}$.

The use of the Cr-resistant fungus Paecilomyces lilacinus to remove $\mathrm{Cr}(\mathrm{VI})$ from two physicochemically different undiluted tannery industry effluents was studied by Sharma et al.[ 39]. The fungus has broad $\mathrm{pH}$ tolerance range and can 
reduce $\mathrm{Cr}(\mathrm{VI})$ both in acidic (pH 5.5) and alkaline (pH 8.0) conditions. Saccharomyces cerevisiae has the ability to sorb $\mathrm{Cr}(\mathrm{VI})$ and the sorption capacity of dehydrated cells is considerably higher than that of intact cells [40]. The removal rate of $\mathrm{Cr}(\mathrm{VI})$ by biomass of marine Aspergillus niger was increased with a decrease in $\mathrm{pH}$ and an increase in $\mathrm{Cr}(\mathrm{VI})$ and biomass concentration.

A. niger exhibited the highest $\mathrm{Cr}(\mathrm{VI})$ uptake of $117.33 \mathrm{mg} / \mathrm{g}$ of biomass at $\mathrm{pH} 1.0$ in the presence of $400 \mathrm{mg} / \mathrm{lr}$ (VI) at $50{ }^{\circ} \mathrm{C}[41]$.

Chromium can be successfully removed by Aspergillus spp [31], Aspergillus carbonarius NRC401121 [42], Aspergillus sp. [43].

\section{Removal mechanism}

The heavy metal biosorption capacity of microorganisms is good because of their large surface area and complex cell wall, which is composed of fiber-like structure and an amorphous embedding matrix of various functional groups such as carboxyl, hydroxyl, amines, phosphates sulfates, etc., which can attracts and sequester the heavy metal ions [41, 19].

In contrast to other metals, which predominantly form cationic species, $\mathrm{Cr}$ exists mainly in the oxyanion form $\left(\mathrm{CrO}_{4}^{2-}\right)$ and thus cannot be trapped by the anionic components of bacterial envelopes [6]. At lower $\mathrm{pH}$, the negatively charged chromium species bind through electrostatic attraction to positively charged functional groups on the surface of biomass cell wall because more functional groups carrying positive charges would be exposed. As $\mathrm{pH}$ increased, the overall surface charge on cell walls became negative and biosorption decreased [5, 43]. Adsorption of $\mathrm{Cr}(\mathrm{VI})$ is not significant at $\mathrm{pH}$ values more than 6 due to dual complexation of the anions $\left(\mathrm{CrO}_{4}^{2-}, \mathrm{Cr}_{2} \mathrm{O}_{7}^{2-}\right.$ and $\left.\mathrm{OH}^{-}\right)$to be adsorbed on the surface of the adsorbents, of which $\mathrm{OH}^{-}$predominates [7].

The $\mathrm{Cr}$ (VI) biosorption process included three steps as depicted in Figure 1.:

(1) the binding of anionic $\mathrm{Cr}(\mathrm{VI})$ ions with the positively charged groups present on the biomass surface;

(2) the reduction of $\mathrm{Cr}(\mathrm{VI})$ to $\mathrm{Cr}(\mathrm{III})$ by adjacent electron-donor groups;

(3) the release of the $\mathrm{Cr}(\mathrm{III})$ ions into the aqueous phase due to electronic repulsion between the positively charged groups and the $\mathrm{Cr}(\mathrm{III})$ ions, or the formation of complexes of the $\mathrm{Cr}$ (III) with adjacent groups capable of Cr-binding.

\section{Aqueous Solution}
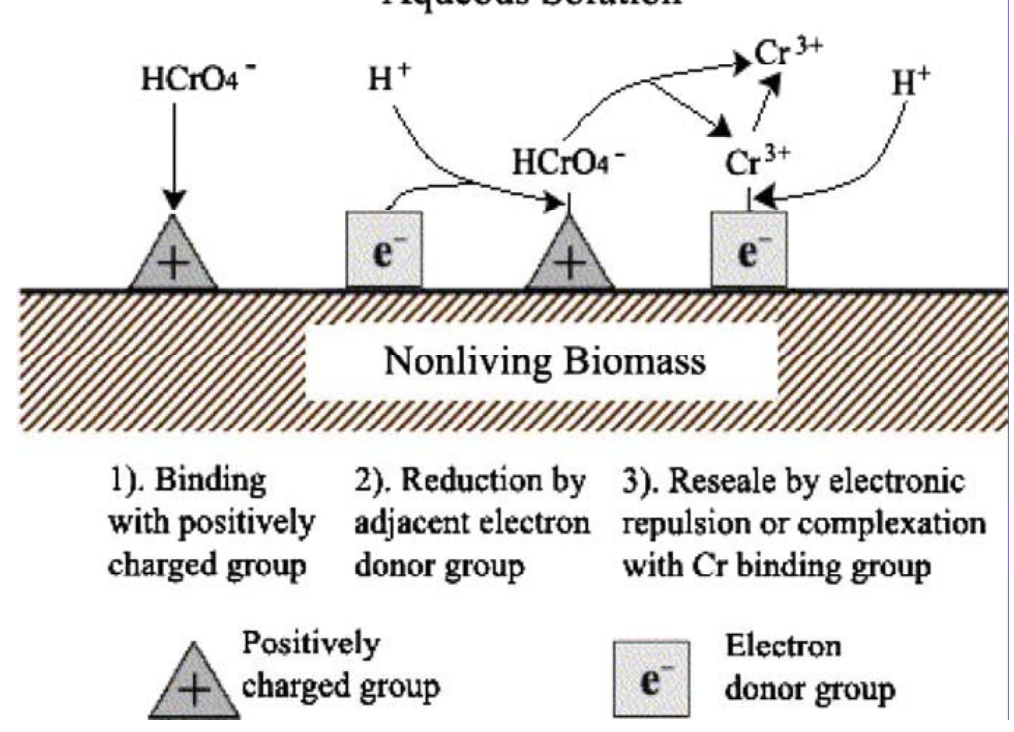

Fig. 1. Proposed mechanism of $\mathrm{Cr}(\mathrm{VI})$ biosorption by nonliving biomass [5]

\section{Adsorption isotherms}

Sorption equilibrium can be described by a number of models available in the literature [44].

Although the Langmuir and Freundlich isotherms were first introduced about 90 years ago, they still remain the two most commonly used adsorption isotherm equation. Their success undoubtedly reflect their ability to fit a wide variety of adsorption data quite well, but it may also partly reflect the appealing simplicity of the isotherm equations and the ease with which their adjustable parameters can be estimated [45, 24].

The Langmuir equation the most widely used isotherm equation for modeling adsorption equilibrium data [14, $46,47-54]$. This model is based on the assumption that the sorption energy is uniform and homogeneously distributed on the sorbent surfaces. 
The Langmuir isotherm model is expressed as:

$$
q=\frac{q_{\max } b c}{1+b c}
$$

Here

$c$ - is the concentration of metal ions; $q_{\max }$ - represents the maximum metal accumulation;

$b$ - is the affinity parameter of the isotherm reflecting the high affinity of the biosorbent for the sorbate [55].

The Freundlich equation is often considered to be purely empirical in nature $[50-54,56]$.

The Freundlich adsorption isotherm is mathematically expressed as

$x / m=K c^{1 / n}$

It is also can be written as

$\log (x / m)=\log k+(1 / n) \log c$

where

$\mathrm{x}=$ mass of adsorbate; $\mathrm{m}=$ mass of adsorbent; $\mathrm{c}=$ equilibrium concentration of adsorbate in solution; $\mathrm{K}$ and $\mathrm{n}$ are constants for a given adsorbate and adsorbent at a particular temperature [57].

Langmiur and Freundlich isotherms are homogeneous models. To describe adsorbtion processe in heterogeneous materials Langmuir- Freundlich (LF) model is applied [58-63].

$$
q=\frac{q_{\max }(b c)^{n}}{1+(b c)^{n}}
$$

Here $c$ is the concentration of metal ions; $q_{\max }$ represents the maximum metal accumulation; $b$ is the affinity parameter of the isotherm reflecting the high affinity of the biosorbent for the sorbate, and $n$ is the empirical parameter that varies with the degree of heterogeneity.

Other types of adsorption isotherms are well described elsewhere [64, 18, 19, 45].

\section{Conclusions}

The present review shows that microorganisms represent an efficient and potential class of biosorbents for the removal of hexavalent chromium from industrial wastewater.

The next step of research is the assessment of the capability of microalgae Spirulina platensis, Nostoc paludosum and Porphyridium cruentum cells to remove chromium ions from wastewater of engineering company of Republic of Moldova. Elemental content of microalgae will be determined by epithermal neutron activation analysis (ENAA) at the reactor IBR-2, FLNP JINR, Dubna, Russia.

\section{References}

[1]. Lloyd, J. R.; Lovley, D. R. Environ. Biotechnol, 12, 2001, 3, 248-253.

[2]. Baldi, F.; Vaughan, A. M.; Olson, G. J. Appl. Environm. Microbiol. 1990, 56(4), 913-918

[3]. Mabbett, A. N.; Macaskie, L. E. Biotechnol. Lett. 2001, 23, 683-687.

[4]. Kaushik, S.; Juwarkar, A.; Malik, A.; Satya, S. J. Environ. Sci. Health: Part A. 2008, 43, 419-423.

[5]. Deng, L.; Zhang, Y.; Qin, J.; Wang, X.; Zhu X. Miner. Eng. 2009, 22, 372-37.

[6]. Cervantes, C.; Campos-Garcia, J.; Devars, S.; Gutierrez-Corona, F.; Loza-Tavera, H.; Torres-Guzman, J. C.; Moreno-Sanchez, R. FEMS Microbiol. Rev. 2001, 25, 335-347.

[7]. Singha, B.; Kumar Das S. Colloids Surf. B. 2011, 84, 221-232.

[8]. Liu Y.; Feng B.; Fan T.; Zhou H.; Li X. Trans. Nonferrous Met. Soc. China. 2008, 18, 480-487.

[9]. Kim, E. J.; Park, S.; Hong, H. J.; Cho, Y. E.; Yang, J.-W. Bioresource Technol, 2011, (Article in press).

[10]. Alam, M. Z.; Ahmad, S. Clean - Soil, Air, Water. 2011, 39 (3), 226-237.

[11]. Dhankhar, R.; Guriyan, R. B. Int. J. Adv. Sci. Technol. 2011, 2(6), 103-128.

[12]. Mishra, S.; Doble, M. Ecotox. Environ.1 Safe. 2008, 71, 874-879.

[13]. Dursun, A.Y. Biochem. Eng. J. 2006, 28, 187-195.

[14]. Sag, Y.; Yalcuk, A.; Kutsal, T. Hydrometallurgy, 2001, 59, 77-87.

[15]. Beolchini, F.; Pagnanelli, F.; Toro, L.; Veglio, F. Hydrometallurgy, 2005, 76, 73-85.

[16]. Ileri, R.; Mavituna, F. Trans IChemE, 1998, 76, Part B, 249-258.

[17]. Xie, S.; Yang, J.; Chen, C.; Zhang, X.; Wang, Q.; Zhang, C. J. Environ. Radioactiv. 2008, 99, 126-133.

[18]. Akar, T., Anilan, B.; Gorgulu, A.; Akar, S. T. J. Hazard. Mater. 2009, 168, 1302-1309.

[19]. Vijayaraghavan, K.; Yun, Y.S. Biotechnol. Adv., 2008, 26, 266-291.

[20]. Tsezos, M.; Remoudaki, E.; Angelatou, V. Camp. Biochem. Physiol., 1997, 118A(3), 481-487. 
[21]. Tarangini, K.; Kumar, A.; Satpathy, G. R.; Sangal, V. K. Clean. 2009, 37 (4), 319 - 327.

[22]. Loukidou, M. X.; Zouboulis, A. I.; Karapantsios, T. D.; Matis K. A. Colloids and Surfaces A: Physicochem. Eng. Aspects. 2004, 242, 93-104.

[23]. Anjana, K.; Kaushik, A.; Kiran, B.; Nisha, R. J. Hazard. Mater. 2007, 148, 383-386.

[24]. Ozdemir, G.; Ceyhan, N.; Ozturk, T.; Akirmak, F.; Cosar, T. Che Eng J. 2004, 102, 249-253.

[25]. Congeevaram, S.; Dhanarani, S.; Park, J.; Dexilin, M.; Thamaraiselvi, K. J. Hazard. Mater. 2007, 146, 270277.

[26]. Parameswari, E.; Lakshmanan, A.; Thilagavathi, T. EJEAFChem. 2009,8 (3), 150-156.

[27]. Ilhan, S.; Nourbacksh, M. N.; Kilicarslan, S.; Ozdag, H. Turkish Electron. J. Biotechnol. 2004, 2, $50-57$.

[28]. Zhou, M.; Liu, Y.; Zeng, G.; Li, X.; Xu, W.; Fan, T. World J. Microbiol. Biotechnol. 2007, 23, 43-48.

[29]. Gabr, R. M.; Gad-Elrab, S. M. F.; Abskharon, R. N. N.; Hassan, S. H. A.; Shorei, A. A. M. World J. Microbiol. Biotechnol. 2009, 25, 1695-1703.

[30]. Aravindhan, R.; J. Sreeram, K.; Rao, J. R., Nair, B. U. J. Gen. Appl. Microbiol. 2001, 53, 71-79.

[31]. Pei, Q. H.; Shahir, S.; Santhana Raj, A. S.; Zakaria, Z. A.; Ahmad, W. A. World J. Microbiol. Biotechnol. 2009, 25, 1085-1093.

[32]. Dwivedi, S.; Srivastava, S.; Mishra, S.; Kumar, A.; Tripathi, R. D.; Rai, U. N.; Dave, R.; Tripathi, P.; Charkrabarty, D.; Trivedi, P. K. J. Hazard. Mater. 2010,173, 95-101.

[33]. Sampedro, M.A.; Blanco, A.; Llama, M.J.; Serra, J.L. Biotechnol. Appl. Biochem.1995, 22, 355-366.

[34]. Kim, E. J., Park, S., Hong, H.J.; Cho, Y.E.; Yang, J.W. Bioresource Technol, 2011, (Article in press).

[35]. Travieso, L.; Cañizares, R. O.; Borja, R.; Benítez, F.; Domínguez, A. R.; Dupeyrón, R.; Valiente, V. Bull. Environ. Contam. Toxicol. 1999, 62, 144-151.

[36]. Saha, B.; Orvig, C. Coordin. Chem. Rev. 2010, 254, 2959-2972.

[37]. Sen, M.; Ghosh Dastidar, M. Iran. J. Environ. Health. Sci. Eng., 2010, 7(3), 182-190.

[38]. Chen, G.Q., Zhang, W.J., Zeng, G. M.; Huang, J. H.; Wang, L.; Shen, G.L. J. of Hazard. Mater. 2011, 186, 2138-2143.

[39]. Sharma, S., Adholeya, A. Int. Biodeter. Biodeg. 2011, 65, 309-317.

[40]. Paknikar, K.M.; Bhide, J.V. In: Biohydrometallurgical Technologies. 1993; pp. 237-244.

[41]. Akhtar, N.; Iqbal, M.; Zafar, S. I.; Iqbal, J. J. Environ. Sci. 2008, 20, 231-239.

[42]. Al-Asheh, S.; Duvnjak, Z. Biotechnol. Prog. 1995, 11, 638-642.

[43]. Congeevaram, S.; Dhanarani, S.; Park, J.; Dexilin, M.; Thamaraiselvi, K. J. Hazard. Mater. 2007, 146, 270277.

[44]. A. Witek-Krowiak, R. G. Szafran, S. Modelski. Biosorption of heavy metals from aqueous solutions onto peanut shell as a low-cost biosorbent. Desalination 2011, 265, 126-134.

[45]. Kinnlburgh, D.G. Environ.Sci.Technol. 1986, 20, 895-904.

[46]. Chong, K. H.; Volesky, B. Biotechnol. Bioeng. 1995, 47, 451-460.

[47]. Wilson, D. J.; Jones, M. G.; Jones M. M. Chem. Res. Toxicol. 1989, 2 (2), p123-130.

[48]. Crist, R. H.; Martin, J. R.; Carr, D.; Watson, J. R.; Clarke, H. J.; Carr. D. Environ. Sci. Technol. 1994, 28 (11), 1859-1866.

[49]. Vecchio, A.;Finoli, C.; Di Simine, D.; Andreoni, V. Fresenius J. Anal. Chem. 1998, 361, 338-342.

[50]. Kumar, I. N.; Oommen, C.; Kumar, R. N. American-Eurasian J. Agric. Environ. Sci. 2009, 6 (3), $317-323$.

[51]. Erdem, E.; Karapinar, N.; Donat, R. J. Colloid Interface Sci. 2004, 280, 309-314.

[52]. Abdullah, L. C.; Shima, M. S.; Choong, T.S. Y. Pertanika J. Sci. Technol. 2010, 18 (1), 83 - 93.

[53]. Souag, R.; Touaibia, D.; Benayada, B.; Boucenna, A. Eur. J. Sci. Res. 2009, 35(3), 416-425.

[54]. Li, J.; Werth, C.J. Environ. Toxicol. Chem. 2002, 21(7), 1377-1383.

[55]. Basar, C. A. Journal of Hazardous Materials, 2006, B135, 232-241.

[56]. Hussain, A.; Ghafoor, A.; Anwar-ul-Haq, M.; Nawaz, M. Intern. J. Agr. Biol. 2003, 5(3), 349-356.

[57]. Xie, S.; Yang, J.; Chen, C.; Zhang, X.; Wang, Q.; Zhang, C. J. Environ. Radioactiv. 2008, 99, 126-133.

[58]. Tsibakhashvili, N.; Kalabegishvili, T.; Mosulishvili, L.; Kirkesali, E.; Kerkenjia, S.; Murusidze, I.; Holman, H.-Y.; Frontasyeva, M. V.; Gundorina S. F. J. Radioanal. Nucl. Chem. 2008, 278(3), 565-569.

[59]. Kalabegishvili, T. L.; Murusidze, I.; Pataraya, D. T.; Ginturi, E.; Frontasyeva, M. V.; Kirkesali, E. I.; Duca, Gh.; Zinicovscaia, I. Chem. J. Mold. 2011, 6 (1), 6-9.

[60]. Umpleby, R. J.; Baxter, S. C.; Chen, Y.; Shah, R. N.; Shimizu, K. D. Anal. Chem., 2001, 73 (19), $4584-4591$.

[61]. Tsai, S. C.; Juang, K.W.; Jan, Y. L. J. Radioanal. Nucl. Chem. 2005, 266(1), 101-105.

[62]. Damodaran, V. B.; Fee, C. J.; Popat, K. C. Appl. Surf. Sci. 2010, 256, 4894-4901.

[63]. Bennajaha, M.; Darmaneb, Y.; Ebn Touhamic, M.; Maalmia, M. Int. J. Eng. Sci. Technol. 2010, 2(12), $42-52$.

[64]. Dursun, A.Y. Biochemical Engineering Journal, 2006, 28, 187-195. 